\title{
EVIDENCE FOR NATRIURETIC PEPTIDES A AND B AS NON-INVASIVE MARKERS IN CONGENITAL AND VALVULAR HEART DISEASE
}

\author{
Karel Kotaska*, Richard Prusa
}

\author{
Department of Clinical Biochemistry and Pathobiochemistry, 2nd Faculty of Medicine, Charles University, Faculty Hospital \\ Motol, Prague, Czech Republic \\ E-mail: kotaska@email.cz
}

Received: September 1, 2009; Accepted: January 22, 2010

Key words: Natriuretic peptides/Congenital and valvular heart diseases/Reference values/Age and gender relationship

\begin{abstract}
Aim. The aim of this study was to evaluate the diagnostic utility of natriuretic peptides of type A and B as noninvasive markers in the diagnosis and treatment of congenital and valvular heart disease.

Methods. Blood samples from 82 patients with various congenital and valvular heart diseases were measured for A and B natriuretic peptide levels and levels compared with those in a reference group of blood donors. Electrochemiluminiscence immunoassay and immunoluminometric essay were used for quantification of natriuretic peptides A and B. Particular reference values in serum or plasma of blood donors were adapted from literature.

Results. Natriuretic peptide levels in cardiac patients were significantly higher than reference levels. The levels of both peptides in blood serum or plasma showed positive correlation with age, gender and disease severity.

Conclusions. Natriuretic peptides are efficient, non-invasive cardiac markers for facilitating diagnosis, management and treatment of valvular heart disease.
\end{abstract}

\section{INTRODUCTION}

Valvular heart disease is any disease process involving one or more of the valves of the heart (the aortic and mitral valves on the left and the pulmonary and tricuspid valves on the right). Valve problems may be congenital (inborn) or acquired (due to another cause later in life).

Heart valve dysplasia is an error in the development of any of the heart valves, and a common cause of congenital heart defects in humans as well as animals; tetralogy of Fallot is a congenital heart defect with four abnormalities, one of which is stenosis of the pulmonary valve. Ebstein's anomaly is an abnormality of the tricuspid valve. Valvular heart disease is commonly caused by damage to the heart muscle as a result of rheumatic fever or a congenital abnormality. Valvular heart problems can be corrected surgically, by direct repair of the valve, replacement of the damaged valve with an artificial valve, or by a non-surgical technique called balloon valvuloplasty. Patients with valvular heart disease are also at risk for bacterial endocarditis. Cardiac auscultation and various non-invasive and invasive cardiac tests are necessary to establish a firm diagnosis which is the basis for rational treatment of the underlying disorder. Two-dimensional and Doppler echocardiography is particularly useful in this regard ${ }^{1}$. This study provides evidence for the natriuretic peptides (NT-proBNP-N-terminal pro-brain natriuretic peptide and atrial natriuretic peptide -proANP) as non-invasive cardiac markers in establishing diagnosis, management and treatment of congenital and valvular heart diseases.

\section{MATERIALS AND METHODS}

\section{Patients}

Eighty two samples of both blood serum or blood plasma from patients ( 36 males, mean age of 46 years, range 22-75 years and 46 females, mean age of 45 years, range 22-79 years) with various types of valvular heart diseases were collected for investigation of serum NT-proBNP levels and plasma mid-regional proANP levels. Consecutive ambulatory patients were previously examined in a specialized Cardiology Department. Clinically relevant indices (hypertension, history of acute myocardial infarction, treatment by angiotensin converting enzyme (ACE) inhibitors and angiotensin antagonists, beta blockers and diuretics, left ventricular ejection fraction, systolic and diastolic pressure and kidney function expressed as S-creatinine levels) were investigated. Echocardiography was used to determine the degree of severity of the heart diseases.

Patient characteristic are listed in Table 1.

\section{Methods}

Blood samples were collected by venipuncture into tubes (Sarstedt, Vacutainer) containing EDTA as an anticoagulant. Immediately after the collection were samples transported in laboratory and after centrifugation $(4000 \mathrm{~g}$ at $4^{\circ} \mathrm{C}$ and $10 \mathrm{~min}$ ) the aliquots of serum and plasma were frozen immediately and kept at $-20^{\circ} \mathrm{C}$ until proANP and NT-proBNP were analyzed. Serum levels of NT-proBNP were measured using a commercially available electrochemiluminescence sandwich immunoassay (ECLIA, Roche, Germany) on Elecsys System 2010. Plasma mid-re- 
Table 1. Characteristic of the patients.

\begin{tabular}{|c|c|c|c|}
\hline & Males & Females & Total \\
\hline $\mathrm{N}$ & 36 & 46 & 82 \\
\hline LVEF (Mean \pm SD) $(\%)$ & $49.2 \pm 18.2$ & $60.2 \pm 14.3$ & $55.0 \pm 16.9$ \\
\hline N-MID-proANP (mean \pm SEM) (pmol/1) & $191.0 \pm 39$ & $120.7 \pm 25.5$ & $154.6 \pm 23.5$ \\
\hline NT-proBNP $($ mean \pm SEM) $(\mathrm{pg} / \mathrm{ml})$ & $2051.6 \pm 657.2$ & $795.4 \pm 118.5$ & $1360.0 \pm 298.4$ \\
\hline Hypertension $(\%)$ & $19(53)$ & $22(48)$ & $41(50)$ \\
\hline $\begin{array}{l}\text { Systolic pressure }[\mathrm{mm} \mathrm{Hg}](\text { mean } \pm \mathrm{SD}) \\
\text { Diastolic pressure }[\mathrm{mm} \mathrm{Hg}](\text { mean } \pm \mathrm{SD})\end{array}$ & $\begin{array}{c}129.1 \pm 19.4 \\
78.7 \pm 10.7 \\
\end{array}$ & $\begin{array}{c}123.3 \pm 18.3 \\
75.3 \pm 12.4\end{array}$ & $\begin{array}{c}125.8 \pm 18.8 \\
76.8 \pm 11.7 \\
\end{array}$ \\
\hline Creatinine $[\mu \mathrm{mol} / 1]($ mean $\pm \mathrm{SD})$ & $101.8 \pm 33.3$ & $77.9 \pm 13.1$ & $89.4 \pm 27.4$ \\
\hline History of AMI (\%) & $14(38)$ & $13(28)$ & $27(33)$ \\
\hline $\begin{array}{l}\text { ACE inhibitors (\%) } \\
\text { Angiotensin antagonists (\%) } \\
\text { Beta blockers (\%) } \\
\text { Diuretics }(\%)\end{array}$ & $\begin{aligned} 10 & (28) \\
2 & (6) \\
14 & (39) \\
14 & (39)\end{aligned}$ & $\begin{array}{c}13(28) \\
0 \\
13(28) \\
13(28) \\
\end{array}$ & $\begin{aligned} 23 & (28) \\
2 & (2) \\
27 & (33) \\
27 & (33)\end{aligned}$ \\
\hline Atrial stenosis & 1 & 1 & 2 \\
\hline Atrial septal defect & 8 & 15 & 23 \\
\hline Atrial regurgitation & 2 & 0 & 2 \\
\hline Atrioventricular septal defect & 0 & 2 & 2 \\
\hline $\begin{array}{l}\text { Transposition and corrected transposition } \\
\text { of great arteries }\end{array}$ & 7 & 5 & 12 \\
\hline Tricuspidal atresia & 2 & 1 & 3 \\
\hline Ventricular septal defect & 2 & 6 & 8 \\
\hline Ebstein anomaly & 2 & 5 & 7 \\
\hline Tricuspidal and atrial regurgitation & 0 & 1 & 1 \\
\hline Mitral valve prolapse & 0 & 1 & 1 \\
\hline Tetralogy of Fallot & 3 & 1 & 4 \\
\hline Dilated cardiomyopathy & 1 & 0 & 1 \\
\hline $\begin{array}{l}\text { Eisenmenger syndrome and heavy pulmo- } \\
\text { nal hypertension }\end{array}$ & 1 & 4 & 5 \\
\hline Pulmonary valve stenosis & 1 & 1 & 2 \\
\hline Mitral regurgitation & 1 & 1 & 2 \\
\hline $\begin{array}{l}\text { Coronary artery bypass graft and mitral } \\
\text { regurgitation }\end{array}$ & 4 & 0 & 4 \\
\hline Coarctation of the aorta & 1 & 1 & 2 \\
\hline Patent ductus arteriosus & 0 & 1 & 1 \\
\hline
\end{tabular}

gional proANP levels were measured by using a sandwich immunoluminometric assay for mid-regional proANP (amino acids 53-90) (BRAHMS SERISTRA, BRAHMS AG, Germany) as previously described in Morgenthaler et $\mathrm{al}^{2}$.

\section{Statistical analysis}

Differences between the medians for reference values of both natriuretic peptides and the medians in patients with valvular heart diseases were tested for statistical significance by the Wilcoxon Signed rank test. $\mathrm{P}<0.05$ was considered as statistically significant difference.

\section{RESULTS}

Blood serum and plasma concentrations of both natriuretic peptides were significantly elevated in patients with congenital and valvular heart disease as compared with reference values. Both peptides showed positive correlation with age and gender. A summary of the results is shown in Table 2.

The non significant differences in the group of males over 60 years for NT-proBNP, and in females over 56 years for N-MID-proANP may have been due to large variability and range of results (males over 60years: NTpro BNP range $60-16071 \mathrm{pg} / \mathrm{ml}$; females over 56 years: N-MID-proANP range 83-280 pmol/1). Serum levels of NT-proBNP in patients were significantly elevated above the cut off values $(100 \mathrm{pg} / \mathrm{ml}$ for males, $150 \mathrm{pg} / \mathrm{ml}$ for 
Table 2. Correlation of natriuretic peptides with age gender and reference values in patiens with congenital and valvular heart diseases adpated from², 16, 20 .

\begin{tabular}{|c|c|c|c|c|c|}
\hline $\begin{array}{l}\text { Natriuretic } \\
\text { peptides }\end{array}$ & $\begin{array}{r}\text { Reference values - B } \\
\text { (Median) }\end{array}$ & $\begin{array}{l}\text { Blood donors } \\
\text { ) }\end{array}$ & $\begin{array}{r}\text { Patients va } \\
\text { (Median }\end{array}$ & & $\begin{array}{c}\text { P value } \\
\text { (Significance) }\end{array}$ \\
\hline $\begin{array}{l}\text { NT-proBNP } \\
\text { (age, gender) }\end{array}$ & $\begin{array}{l}\text { Males } 18-54 \text { years: } \\
\text { Males } 54-64 \text { years: } \\
\text { Males > } 64 \text { years: } \\
\text { Females } 18-54 \text { years: } \\
\text { Females } 54-64 \text { years: } \\
\text { Females > } 64 \text { years: }\end{array}$ & $\begin{array}{r}20.8 \mathrm{pg} / \mathrm{ml} \\
29.7 \mathrm{pg} / \mathrm{ml} \\
117.5 \mathrm{pg} / \mathrm{ml} \\
46.3 \mathrm{pg} / \mathrm{ml} \\
67.5 \mathrm{pg} / \mathrm{ml} \\
138.1 \mathrm{pg} / \mathrm{ml}\end{array}$ & $\begin{array}{l}\text { Males } 18-54 \text { years: } \\
\text { Males } 54-64 \text { years: } \\
\text { Males > 64 years: } \\
\text { Females } 18-54 \text { years: } \\
\text { Females } 54-64 \text { years: } \\
\text { Females > } 64 \text { years: }\end{array}$ & $\begin{array}{r}310.8 \mathrm{pg} / \mathrm{ml} \\
1913 \mathrm{pg} / \mathrm{ml} \\
500.8 \mathrm{pg} / \mathrm{ml} \\
334.3 \mathrm{pg} / \mathrm{ml} \\
239.9 \mathrm{pg} / \mathrm{ml} \\
760.3 \mathrm{pg} / \mathrm{ml}\end{array}$ & $\begin{array}{l}\mathrm{p}<0.0001 \\
\mathrm{p}=0.0156 \\
\mathrm{p}=0.1250 \\
\mathrm{p}<0 .(\mathrm{S}) \\
\mathrm{p}=0.0001 \\
\mathrm{p}=0.0033\end{array}$ \\
\hline N-MID-proANP & $\begin{array}{l}\text { Whole group: } \\
\text { Males: } \\
\text { Females }\end{array}$ & $\begin{array}{r}45 \mathrm{pmol} / 1 \\
45.3 \mathrm{pmol} / 1 \\
45 \mathrm{pmol} / 1\end{array}$ & $\begin{array}{l}\text { Whole group: } \\
\text { Males: } \\
\text { Females: }\end{array}$ & $\begin{array}{r}106 \mathrm{pmol} / 1 \\
212 \mathrm{pmol} / 1 \\
85.8 \mathrm{pmol} / 1\end{array}$ & $\begin{array}{ll}\mathrm{p}<0.0001 & (\mathrm{~S}) \\
\mathrm{p}=0.0012 & (\mathrm{~S}) \\
\mathrm{p}=0.0002 & (\mathrm{~S})\end{array}$ \\
\hline $\begin{array}{l}\text { N-MID-proANP } \\
\text { (age, gender) }\end{array}$ & $\begin{array}{l}\text { Males } 18-25 \text { years: } \\
\text { Males } 26-35 \text { years: } \\
\text { Males } 36-45 \text { years: } \\
\text { Males } 46-55 \text { years: } \\
\text { Males } 56-65 \text { years: } \\
\text { Females } 18-25 \text { years: } \\
\text { Females } 26-35 \text { years: } \\
\text { Females } 36-45 \text { years: } \\
\text { Females } 46-55 \text { years: } \\
\text { Females } 56-65 \text { years: }\end{array}$ & $\begin{array}{r}35 \mathrm{pmol} / 1 \\
31.7 \mathrm{pmol} / 1 \\
44 \mathrm{pmol} / 1 \\
57.4 \mathrm{pmol} / 1 \\
64.8 \mathrm{pmol} / 1 \\
43.3 \mathrm{pmol} / 1 \\
: 45.1 \mathrm{pmol} / 1 \\
: 41.1 \mathrm{pmol} / 1 \\
: 41.4 \mathrm{pmol} / 1 \\
68.6 \mathrm{pmol} / 1\end{array}$ & $\begin{array}{l}\text { Males } 18-25 \text { years: } \\
\text { Males } 26-35 \text { years: } \\
\text { Males } 36-45 \text { years: } \\
\text { Males } 46-55 \text { years: } \\
\text { Males } 56-65 \text { years: } \\
\text { Females } 18-25 \text { years: } \\
\text { Females } 26-35 \text { years: } \\
\text { Females } 36-45 \text { years: } \\
\text { Females } 46-55 \text { years: } \\
\text { Females } 56-65 \text { years: }\end{array}$ & $\begin{array}{r}71.5 \mathrm{pmol} / 1 \\
141.6 \mathrm{pmol} / 1 \\
68.1 \mathrm{pmol} / 1 \\
225 \mathrm{pmol} / 1 \\
212 \mathrm{pmol} / 1 \\
61.6 \mathrm{pmol} / 1 \\
238.5 \mathrm{pmol} / 1 \\
48.8 \mathrm{pmol} / 1 \\
83 \mathrm{pmol} / 1 \\
115.5 \mathrm{pmol} / 1\end{array}$ & $\begin{array}{l}\mathrm{p}=0.0005 \\
\mathrm{p}=0.0002 \\
\mathrm{p}=0.0012 \\
\mathrm{p}=0.0081 \\
\mathrm{p}=0.0081 \\
\mathrm{p}=0.0002 \\
\mathrm{p}=0.0002 \\
\mathrm{p}=0.0002 \\
\mathrm{p}=0.0002 \\
\mathrm{p}=0.058\end{array}$ \\
\hline
\end{tabular}

Reference values of both natriuretic peptides were calculated from the group of healthy blood donors and were previously published in ${ }^{2,16,20}$. Wilcoxon Signed rank test was used to test the statistical significance between medians of reference group and patients with congenital and valvular heart disease. Value of $p<0.05$ was considered as significant difference.

S- significant, NS- non-significant

females and $125 \mathrm{pg} / \mathrm{ml}$ for all patients) approved for the NT-proBNP assay. The blood serum and plasma levels of both natriuretic peptides correlate well with the measured cardiological parameters (diastolic blood pressure and systolic blood pressure, left ventricular ejection fraction (LVEF), history of acute myocardial infarction (AMI)).

\section{DISCUSSION}

The presented study shows the complex approach to investigation of valvular heart diseases with biochemical and cardiovascular surveillance of patients.

To date, several studies show the relevance of natriuretic peptides in valvular and congenital heart diseases. The present results confirm the findings of other studies showing significantly elevated levels of natriuretic peptides in various types of congenital and valvular heart diseases $^{3-5}$. Other studies have shown a relationship between concentrations of natriuretic peptides and severity of heart failure ${ }^{6-12}$. In agreement with previous publications $^{6-12}$, the levels of both natriuretic peptides increased with severity of the heart impairment. The highly significant relationship to age and gender for both natriuretic peptides found, accords with other studies ${ }^{13-18}$. Diuretics, ACE inhibitors, angiotensin receptor antagonists, beta- blockers and renal impairment have been shown to decrease levels of natriuretic peptides ${ }^{19}$. In the present study, 27 of 82 patients were treated by drugs but only three of these patients showed significantly lower values of NTproBNP and NT-proANP. Nevertheless, these results correlated with increase of the left ventricular ejection fraction (over $60 \%$ ) resulting in less severe heart impairment. Values of S-creatinine were investigated as a marker of renal impairment. In 80 of 82 patients, the results show normal levels of S-creatinine according to the age and gender. One patient had mildly elevated levels of S-creatinine $(130 \mu \mathrm{mol} / \mathrm{l})$ and one patient had significantly elevated level of S-creatinine $(200 \mu \mathrm{mol} / \mathrm{l})$. In both patients, the levels of natriuretic peptides were significantly higher than reference values ( $1^{\text {st }}$ patient: S-creatinine: $130 \mu \mathrm{mol} / 1$, NT-proBNP - $1040 \mathrm{pg} / \mathrm{ml}$, N-MID-proANP $78 \mathrm{pg} / \mathrm{ml} ; 2^{\text {nd }}$ patient: - S-creatinine: $200 \mu \mathrm{mol} / 1$, NT-proBNP -16071 $\mathrm{pg} / \mathrm{ml}$, N-MID-proANP $504 \mathrm{pg} / \mathrm{ml}$ ) In both cases, levels of natriuretic peptides correlated with the severity of heart impairment $(\mathrm{LVEF}=35 \%$ and $10 \%$ respectively $)$.

In conclusion, the results of the present study indicate that the natriuretic peptides (NT-proBNP and N-MIDproANP) are well appropriate as non-invasive cardiac biochemical markers in establishing diagnosis, as well as in management and treatment of valvular and congenital heart diseases. 


\section{ACKNOWLEDGEMENT}

This study was supported by research grant of Ministry of Health MZO 00064203-6306.

\section{REFERENCES}

1. Bonow RO, Carabello BA, Kanu C, de Leon AC, Jr., Faxon DP, Freed MD, et al. ACC/AHA 2006 guidelines for the management of patients with valvular heart disease: a report of the American College of Cardiology/American Heart Association Task Force on Practice Guidelines (writing committee to revise the 1998 Guidelines for the Management of Patients With Valvular Heart Disease): developed in collaboration with the Society of Cardiovascular Anesthesiologists: endorsed by the Society for Cardiovascular Angiography and Interventions and the Society of Thoracic Surgeons. Circulation 2006; 114(5):e84-231.

2. Morgenthaler NG, Struck J, Thomas B, Bergmann A. Immunoluminometric assay for the midregion of pro-atrial natriuretic peptide in human plasma. Clin Chem 2004; 50(1):234-6.

3. Taniguchi R, Sato Y, Nishio Y, Kimura T, Kita T. Measurements of baseline and follow-up concentrations of cardiac troponin-T and brain natriuretic peptide in patients with heart failure from various etiologies. Heart Vessels 2006; 21(6):344-9.

4. Yilmaz MB, Erbay AR, Balci M, Guray Y, Cihan G, Guray U, et al. Atrial natriuretic peptide predicts impaired atrial remodeling and occurrence of late postoperative atrial fibrillation after surgery for symptomatic aortic stenosis. Cardiology 2006; 105(4):207-12.

5. Iivainen TE, Groundstroem KW, Lahtela JT, Talvensaari TJ, Pasternack A, Uusitalo A. Serum N-terminal atrial natriuretic peptide in adult patients late after surgical repair of atrial septal defect. Eur J Heart Fail 2000; 2(2):161-5.

6. Seino Y, Ogawa A, Yamashita T, Fukushima M, Ogata K, Fukumoto $\mathrm{H}$, et al. Application of NT-proBNP and BNP measurements in cardiac care: a more discerning marker for the detection and evaluation of heart failure. Eur J Heart Fail 2004; 6(3):295-300.

7. Almeida P, Azevedo A, Rodrigues R, Dias P, Frioes F, Vazquez B, et al. B-type natriuretic peptide and left ventricular hypertrophy in hypertensive patients. Rev Port Cardiol 2003; 22(3):327-36.

8. Hammerer-Lercher A, Neubauer E, Muller S, Pachinger O, Puschendorf B, Mair J. Head-to-head comparison of N-terminal pro-brain natriuretic peptide, brain natriuretic peptide and
$\mathrm{N}$-terminal pro-atrial natriuretic peptide in diagnosing left ventricular dysfunction. Clin Chim Acta 2001; 310(2):193-7.

9. Hunt PJ, Richards AM, Nicholls MG, Yandle TG, Doughty RN, Espiner EA. Immunoreactive amino-terminal pro-brain natriuretic peptide (NT-PROBNP): a new marker of cardiac impairment. Clin Endocrinol (Oxf) 1997; 47(3): 287-96.

10. McGeoch G, Lainchbury J, Town GI, Toop L, Espiner E, Richards AM. Plasma brain natriuretic peptide after long-term treatment for heart failure in general practice. Eur J Heart Fail 2002; 4(4):47983.

11. Kotaska K, Popelova J, Tiserova M, Telekes P, Vrzanova M, Bronsky J, et al. The relevance of brain natriuretic peptides investigation in various cardiovascular diseases. Biomed Pap Med Fac Univ Palacky Olomouc Czech Repub 2006; 150(2): 285-8.

12. Kotaska K, Popelova J, Tiserova M, Telekes P, Vrzanova M, Bronsky $\mathrm{J}$,et al. NT-proBNP and BNP values in cardiac patients with different degree of left ventricular systolic dysfunction. Biomed Pap Med Fac Univ Palacky Olomouc Czech Repub 2006; 150(1):125-30.

13. Redfield MM, Rodeheffer RJ, Jacobsen SJ, Mahoney DW, Bailey KR, Burnett JC, Jr. Plasma brain natriuretic peptide concentration: impact of age and gender. J Am Coll Cardiol 2002; 40(5):976-82.

14. Jensen KT, Carstens J, Ivarsen P, Pedersen EB. A new, fast and reliable radioimmunoassay of brain natriuretic peptide in human plasma. Reference values in healthy subjects and in patients with different diseases. Scand J Clin Lab Invest 1997; 57(6): 529-40.

15. Clerico A, Del Ry S, Maffei S, Prontera C, Emdin M, Giannessi D. The circulating levels of cardiac natriuretic hormones in healthy adults: effects of age and sex. Clin Chem Lab Med 2002; 40(4):371-7.

16. Hess G, Runkel S, Zdunek D, Hitzler WE. Reference interval determination for N-terminal-B-type natriuretic peptide (NT-proBNP): a study in blood donors. Clin Chim Acta 2005; 360(1-2): 187-93.

17. Alehagen U, Goetze JP, Dahlstrom U. Reference intervals and decision limits for B-type natriuretic peptide (BNP) and its precursor (Nt-proBNP) in the elderly. Clin Chim Acta 2007; 382(1-2): 8-14.

18. Clerico A, Emdin M. Diagnostic accuracy and prognostic relevance of the measurement of cardiac natriuretic peptides: a review. Clin Chem 2004; 50(1):33-50.

19. Angermann CE, Ertl G. Natriuretic peptides-new diagnostic markers in heart disease. Herz 2004; 29(6): 609-17.

20. Hess G, Runkel S, Zdunek D, Hitzler WE. N-terminal pro-brain natriuretic peptide (NT-proBNP) in healthy blood donors and in patients from general practitioners with and without a diagnosis of cardiac disease. Clin Lab 2005; 51(3-4):167-72. 